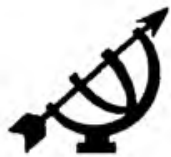

\section{The South African Constitution requires men to be feminist}

\author{
H P.P. Lötter \\ Department of Philosophy \\ Rand Afrikaans University \\ AUCKLANDPARK \\ E-mail: HPPL@Iw.rau ac za
}

Abstract

The South African Constitution requires men to be feminist

Can a man be a feminist? If so, what would it mean? I want to participate in a dialogue between women and men on how to accommodate women's moral concerns. I propose that the fundamental values of justice embodied in the South African constitutional democracy require men to be feminist. These values provide the best safeguard of the important interests and values of both women and men. Men who accept these values can support the main concerns of feminism. The implications of the argument in this article range from public issues to the most private aspects of marriage.

Feminism has firmly established itself as a philosophy of liberation with a strong impact on politics through the women's movement. The impact of the women's movement through the transformation of societies, institutions, and individuals is of such enormous scope that Naomi Wolf is correct in calling it the "most successful and least bloody revolution in human history" (Wolf, 1993:63). However, this revolution is far from over. Feminism still demands serious attention for its diversity of social analyses and normative evaluations of institutions, practices, conventions, and habits.

Can a man be a feminist? If so, what would it mean? Could it mean that a man simply agrees with the feminist critique of male domination and oppression of women in its various guises? Perhaps a feminist man would be one who changes his behaviour towards women so as to remove any semblance of dominating, oppressive, or discriminatory behaviour towards women. A feminist man might even feel so much guilt about his sexist behaviour in the past that he wholly accepts feminist views without critical questioning or normative evaluation. 
In this article I want to argue that the South African Constitution requires men to be feminist. The fundamental values of the Constitution are as follows. The core values of the South African Constitution are equality, freedom, accountability or justification, and openness. The values of the redress of past injustices and an improved quality of life, or the fair distribution of wealth, are also important focuses of the new democratic constitution. These values were developed in relation to South Africa's unjust past and this can be explained as follows (see RSA Const., 1996: Preamble).

Equality stands against political institutions and actions that treated some citizens as being second- and third-class citizens. Discrimination on the basis of arbitrary characteristics such as race is rejected in the new South Africa. Freedom is the value guarding against political institutions and actions that denied black people the standard liberties of modern democracies in the past. A specific example is someone's right to freedom and security. This right explicitly rejects detention without trial, torture of any kind, and cruel, inhuman, or degrading treatment. The right to freedom and security of the person stamps such degrading practices that were perpetrated in the past as unlawful.

Accountability and justification are responses to the authoritarian style of government in the past. Never again should a government be allowed to make decisions without having to account for those decisions to its citizens. Government officials and their bureaucratic agents will have to justify their policies and actions to the citizens of South Africa to minimize the risk of repeating the abuse of power in the past.

Closely associated with accountability is the value of openness. The evil planned behind closed doors and executed in secret by government agents of the apartheid state against citizens was horrifying. Through insisting on an open democracy and openness of governmental action, South Africans intend to avoid the abuse of political power enabled through a lack of public scrutiny

The redress of past injustices is another fundamental value underiying South Africa's new constitution. South Africans have chosen to repair the damage created by apartheid as far as possible. The reparation of the damage of apartheid to the life opportunities of black people will be brought about by affirmative action. Property illegitimately appropriated by the apartheid government must either be returned or be compensated. Closely associated with the redress of past injustices is the value of fair distribution of wealth. New governmental policies specify comprehensive state intervention to focus human and financial resources to alleviate massive poverty directly related to apartheid society's neglect 
of black people. These policies found general acceptance and are strengthened by the ANC government's use of the private initiative of individuals, communities and companies in addressing these issues. The commitment to improve the quality of life of poor people is so strong that socio-economic rights were included in the Constitution of 1996 to bind the government to the goal of alleviating poverty.

Some aspects of the public conception of justice for South Africa are still unclear, controversial, or not yet publicly debated. These undecided aspects provide opportunity for moral debate and political strategy to influence the direction taken. Part of the conception of justice contained in modern liberal democracies, like South Africa, is guaranteed opportunities for citizens to take part in revising and extending this conception. Feminists are exploiting these opportunities to work out what would be more just policies and laws for women and how men ought to behave more justly toward women. Attempts at modifying or extending a conception of justice through debate, argument, mobilization of support, and public demonstrations are ways of peaceful resolution of conflict.

Lasting peace in South Africa will only be possible when the country is fully transformed into a just society. This transformation implies two things. Justice requires looking back in time to undo or compensate for the injustice of the past. Justice further requires looking forward in time to establish just institutions and policies. The issues involved in the transformation of past injustice toward women into future peace between the sexes will now be outlined.

If it is true that the South African Constitution requires men to be feminist, what does it imply? A feminist man is one with good reason to accept many aspects of feminist critique of male domination and oppression that manifest in all spheres of life. Such acceptance must be guided by a dialogue between women and men on a satisfactory shared interpretation of the fundamental values of justice operative in the South African constitutional democracy. In this article I explore some feminist writings with the aim of formulating a normative ideal for men in their relations to women that integrates the main objectives of the feminist critique of patriarchy with the values of justice underlying the South African Constitution. I intend to show that the South African Constitution has implications for men's relations with women that reach beyond the public sphere into the privacy of the household and even the bedroom shared by marriage partners. 


\section{Men ought to take all kinds of injustice seriously}

Why should South African men take feminism seriously? There are a few simple reasons. One reason is that men should take the injustices of sexism at least as seriously as any other comparable injustice in their society. Especially men who have experienced the injustice of racial oppression under apartheid ought to be sensitive to the remaining forms of the oppression of women. Moral consistency requires it. However, men might have to take feminism more seriously than other comparable forms of injustice. Why? One reason is that the injustices of sexism can affect some of the significant women in their lives. If one accepts that one has stronger moral obligations to the most significant people that form part of one's everyday life, then men ought to take the injustice of sexism very seriously. The special women in men's lives are at risk of becoming victims of the injustices of sexism. If they love their mothers, lovers, wives, sisters, and daughters, or have good friends, acquaintances, or colleagues who are female, men themselves might become secondary victims of the trauma one of these women might suffer when becoming a victim of one or more of the injustices of sexism. Another reason for taking sexism seriously is that men themselves might be responsible for injustices of sexism toward women in their everyday lives. They thus have to check whether they violate the warranted claims of injustice expressed by feminism and are thus morally responsible for harming other people.

\section{Women suffer from serious injustices}

What kinds of injustices drive feminist concerns? Are these concerns substantial enough to warrant serious male attention, or are women merely being squeamish? The best way to present the underlying concerns of feminism is to show how many of women's most important human rights - embodied in the South African Constitution - are violated by men. The rights in question are the rights to life, bodily integrity, recognition, liberty, and equality. With the exception of rights to have basic needs fulfilled, all the fundamental rights of scores of women are violated by a large percentage of men. Some detail is needed to sufficiently explain this point. The rights referred to in the following sections are those found in the Bill of Rights of the South African Constitution (RSA Const., 1996).

\section{Violation of rights to bodily integrity}

The first series of human rights violations experienced by women can broadly be categorised as violations of their rights to life and rights to bodily integrity. Some women's right to life are violated by their male partners (RSA Const., 1996: Art. 11). Husbands and boyfriends are re- 
sponsible for $50 \%$ of all women murdered in South Africa, while in the USA the figure is $33 \%$ (cf. Sterba, 1998:89). Many more women have their right to bodily integrity violated as well as their right to be free from all forms of violence (RSA Const., 1996: Art. 12, par. [1]. [2]). One in six South African women are assaulted in their homes by their male partners. In Soweto one in three of the women attending medical clinics have been assaulted by their male partners. In the USA researchers estimate that $50 \%$ of all women are assaulted by their male partners at some or other time in their lives. Assault on women often lead to serious injuries like broken bones or burn wounds.

Rape as sexual violence violates not only the right to be free from all forms of violence and the right to bodily integrity, but also a woman's right to security in and control over her body (RSA Const., 1996: Art. 12, par. [2] b). In South Africa 50481 women reported to the SA Police Services in 1997 that they were raped. Of these cases $43 \%$ of the perpetrators were charged in court resulting in convictions in $8.1 \%$ of the cases. Of all reported rape cases $91.9 \%$ of the alleged perpetrators got away. In one study of 544 victims of rape, researchers found that $87 \%$ percent of the victims were physically threatened with either knives or guns. The perpetrators were known to their victims in $39 \%$ of the cases and in $52 \%$ of the cases the rape took place in either the victim's or the perpetrator's home. Perhaps Andrea Dworkin's (1988) comment that "every woman walking alone is a target" must be modified to "every woman alone in the presence of one or men is a target". The plural here refers to the common occurrence of gang rapes in South Africa as well as in the USA. In the USA approximately $43 \%$ of rapes are committed by two or more men.

If rape is defined as sexual intercourse without the consent of the partner, then sexual abuse of children often comes close to being classified as rape. Many men abuse both their positions of power in households and their intimate family relationships to violate the bodies and minds of young girls. Through their abuse men devastatingly harm these girls. Andrea Dworkin (1988:140) describes the psychological harm as follows: "Her whole system of reality, her whole capacity to form attachments, her whole capacity to understand the meaning of selfrespect, is destroyed by someone she loves". Men sexually abusing young girls in their trust violate the rights of those girls as children to be protected against maltreatment, neglect, abuse or degradation (RSA Const., 1996: Art. 28, par. [1] d). They also violate their rights as children not to be required or permitted to provide services that are inappropriate for a person of that child's age (RSA Const., 1996: Art. 28, par. [1] f (i)). They furthermore violate the children's rights that their well-being, 
The South African Constitution requires men to be feminist

physical or mental health or spiritual, moral or social development should not be placed at risk (RSA Const., 1996: Art. 28, par. [1] f (ii)).

All the different manifestations of violence against women with their associated set of legitimating ideas form one of the main targets of feminism. The seriousness of this issue is underlined by Andrea Dworkin (1988:175) when she says that "crimes of violence against women are human rights violations that occur on a massive, almost unimaginable scale". James Sterba's comment on these American statistics of violence against women is disturbing. What this shows, he says, is that "the condition of women in our society is actually that of being subordinate to men by force" (Sterba, 1998:90). It seems no different in South Africa. What makes these violations of women's rights not to be subject to any kind of violence particularly worrying is that a woman's home has often been called the most dangerous place where she can be. $A$ former Surgeon-General of the USA, Antonia Novello, said that "the home is actually a more dangerous place for the American woman than the city streets" (quoted in Sterba, 1998:89). This seems true for many South African women too. No wonder that feminists have investigated and criticized - in the minutest detail - the dynamics of the household and the legitimating ideas of household practices.

\section{The violation of dignity}

Many women suffer a second series of rights violations simply because they are women. In this series the main issue concerns the appropriate recognition of their equal worth and dignity as human beings (see RSA Const., 1996: Preamble, Art. 1, 10). Several issues spring to mind. Men often use language to belittle and degrade women. Calling women names, e.g. "chicks", making remarks on their physical appearance, and telling jokes stereotyping certain kinds of women are obvious examples. Sexual harassment, which was recognized and named only in the late 1970s (Sterba, 1998:93), has developed into a serious issue that has become outlawed, especially in the workplace. Women experience sexual harassment as humiliating, while they feel "demeaned and devalued" (Sterba, 1998:93).

Sexual harassment - defined as sexual attention forced on women through men in positions of power over them - shows a strong link to men viewing women as sex objects and treating them as if they were nothing more than sexual bodies designed to serve men's gratification. Wolf (1993:210) argues that sexual attention in the context of unequal power often turns a sexual gaze into something that objectifies, belittles, or denigrates women. In relations of equality a sexual gaze can be respectful and express admiration. Anita M. Superson (1993:51) inter- 
HP.P. Lotter

prets the message of a catcall as follows: "a catcall says not [merely] that the perpetrator likes the woman's body but that he thinks women are at least primarily sex objects and he ... gets to rate them according to how much pleasure they give him". Through offensive language, unwelcome sexual attention, and perceptions of women as sexual playthings women's inherent dignity is violated, as well as their rights to have their dignity respected and protected (RSA Const., 1996: Art. 10). Their rights not to be treated in a cruel, inhuman or degrading way are violated too (RSA Const., 1996: Art. 12, par. [1] e). Ann Ferguson (1997:67) states it plainly, "men treat women as inferiors". When strong women act contrary to this ascribed role of being inferior to men, many experience what Patricia Hill Collins (1997:165) says, i.e. that "aggressive, strong women are penalized"

\section{Violations of rights to liberty}

A third series of rights of women that men often violate are rights to liberty. These violations mostly occur within marriage and the family. Many men try to control the movements of their partners or daughters. Some men coerce their partners into submission through short tempers, aggression, insults, or prolonged periods of silence resulting from refusals to discuss shared interests. In many relationships women with stronger personalities are bullied into submission by partners whose feelings of inferiority and beliefs in male superiority cannot allow women to be strong or independent. Through these actions men are violating women's rights to the full and equal enjoyment of all rights and freedoms (RSA Const., 1996: Art. 9, par. [1] [2]).

\section{Violations of the right to equality}

The fourth series of rights of women frequently violated by men are rights to equality. Many stark inequalities between men and women provided the impetus that started the feminist movement. Unequal citizenship rights that excluded women from all forms of political participation were rectified in the first part of the twentieth century in Western countries. Unequal opportunities for education and employment are still being remedied in most countries. Unequal pay for work of comparable worth still exists, albeit far less than in the past.

Women's struggle for equality is far from over. Two issues prove particularly difficult to solve. One issue is men's persistent attitude of superiority. Men everywhere see themselves as the most important part of society and they tend to define humanity in terms of their own image. Nancy J. Chodorow (1997:37) describes this tendency as follows, "men have come to define maleness as that which is basically human, and to define women as not-men". The result is that men often treat women as if 
they cannot make worthwhile contributions, especially in areas traditionally considered to belong to men. Thus, in business, sport, politics, or science, women are often still judged not to be equal partners of similar competence. Uma Narayan (1997:175) articulates the experience of women that "their speech is often ignored or treated with condescension by their male colleagues".

A second persistent site of women's inequality is the household. Two related issues prove to be problematic. One concerns decision-making. Women often experience that they are not equal partners in making decisions about important matters in the household. Whatever role they get in making decisions is assigned to them by their male partner. The male partner's power to do so mostly arise from cultural values about male superiority or the male as provider, more abundant financial means, or greater physical power and the threat of violence. As a result women still have to do the bulk of housework, regardless of their tiresome involvement in raising children or their long hours in pursuit of a career as professional. Adding insult to injury is that most men look down on housework as something below them that would violate their dignity if they had to be known to do it. For this reason Andrea Dworkin (1988:121) observes that "housework is stigmatized as woman's work".

Through men's unfounded attitudes of male superiority and female inferiority and the unequal division of household decision-making and duties, they violate the central thrust of the South African Constitution of treating people equally. Two important rights of women are at issue here. One is that women have the right to equal dignity (RSA Const., 1996: Art. 10). The other right states that neither the state nor any person may discriminate unfairly against anyone on the grounds of, inter alia, gender, sex, pregnancy or marital status (RSA Const., 1996: Art. 9, par. [1], [2], [3], [4]).

It would be a serious mistake to suggest that all women experience the same violations of their rights. Women's experiences of men differ from country to country, but even within the same local community or village women can have different experiences of men, depending on the men in their lives. The diversity of women's experiences in South Africa ranging from multiple, strong forms of sexism to not even noticing sexism - suggest that men have diverse attitudes and actions towards women as well. Some men treat women with proper respect, others treat them with utter disrespect. Nevertheless, there are strong patterns in many societies - South Africa included - of women suffering wide-ranging human rights abuses that warrant serious investigation, strong protest, and clear rejection. 
HP.P. Lotter

\section{Feminism fights to implement an improved conception of justice}

Feminism is a good example of a social movement operative in many countries that wants to eliminate the injustices discussed in the previous section through redefining ideals of justice and giving those ideals new content. What are the shared contents of feminist movements in different countries? The feminist movement articulates a vision of society that would liberate women from their oppression and enable them to live a richer and more rewarding life. To reach the dream of a transformed society, feminists are trying to turn many issues into matters of justice, i.e., they want to bring private matters into the public arena as issues to be debated publicly, evaluated normatively, and decided collectively. I want to show how the central values embodied in the South African Constitution support some of the fundamental ideals articulated by the feminist movement.

To make women's issues matters of justice feminists are trying to convince women that many of their frustrating problems, relationship difficulties, and emotional suffering are not naturally given with roles they simply and unavoidably have to fulfil by divine decree or according to the natural order. Their frustrations, difficulties, and sufferings result from contingent social arrangements and the values embodied in society by the active work of dominant male elites. Women's blindness to seeing these injustices are removed by making them aware that their inferior position in society does not result from unalterable social conditions, fixed natural roles, and true ideas (cf. Okin, 1989:5-6). Rather, their injustices were made by humans and are maintained by men - and women - who arbitrarily define roles for women, and justify those social arrangements through ideas that exclude independent female perspectives.

Feminism aims to create widespread awareness that many social problems and household conditions that are detrimental to women are matters of justice that call for remedy through public, collective action (Benhabib, 1992:109). This aim implies that feminism wants to break decisively with any conception of justice that excludes the household from being morally scrutinized by a conception of justice. The scope of justice is relentlessly extended by feminists to deal with any issue of public interest, provided it can be judged by public morality and be remedied by collective human action. Feminists thus want to make the well-being of individuals, such as a battered wife or a raped woman, matters of justice, despite the supposed privacy of the sphere of family life where these forms of violence often occur. No harm to a woman's life, no violation of a woman's dignity, no constraint on a woman's 
The South African Constitution requires men to be feminist

development, nor any hindrance to a woman's self-determination should be withdrawn from critical testing in terms of the public moral values embodied in a public conception of justice, as expressed in the democratic constitution of South Africa.

\section{The target of injustice feminism aims at}

What exactly is the target of injustice that feminism aims at? The target of feminists is sexism, the cause of their experience of suffering systematic social injustice as a result of their sex (cf. Richards, 1994:2127). Sexism manifests itself as a network of ideas, attitudes, choices, decisions, actions, habits, practices, and institutions that privilege men and disadvantage women. Sexism enables men to dominate women by depriving women of legitimate opportunities for making their own decisions. Sexism also empowers men to oppress women by depriving them of opportunities and spaces for development and growth. Sexism exploits women's group identity through ideas that legitimize men's domination and oppression of women (Wolf, 1994:76). Ideas such as the natural roles of women as mothers and wives, women's lesser rationality, women as the weaker sex, and women's supposedly emotional nature have been used throughout history to justify inferior positions and disrespectful treatment to women.

Feminism tries to provide diagnoses and explanations of sexism (Benhabib, 1992:152). Simone de Beauvoir (1997:9) said it simply: feminists want to know how it is "that this world has always belonged to the men?" Feminists want to pinpoint what they reject about sexism in all its minutest details. They assign responsibility for the manifestations of sexism by pointing out how sexism arose and how it has been maintained. Today the focus is on the persistent tenacity of certain sexist practices and the last vestiges of sexist ideas and behaviour. Through anticipatory-utopian critique feminists are articulating ideals of how society can be changed to remove the injustices women suffer from (Benhabib, 1992:152). In general, feminism wants to make itself superfluous by ridding society of sexism - it does not have the aim to privilege women at the cost of men (cf. Richards, 1994:25). However, the comprehensive network of sexism infiltrated all nooks and crannies of society and thus its eradication takes time and effort To determine what must be done to eliminate sexism completely is an ongoing process. To find appropriate strategies for protest and to set agendas for transformation to create a society where male and female would experience liberty and equality of comparable worth - as promised by the Preamble of the South African Constitution - have proven to be a much bigger and more complex task than most people initially thought 


\section{The struggle aginst sexism}

The struggle against sexism has a particularly difficult nature. Put in war metaphors, both the enemies and the sites of battle make the struggle against sexism difficult. One kind of enemy that feminism fights is sexist men. Not all men are sexist. For some women, however, the enemy is a father, a brother, a lover, a husband, or a friend. Andrea Dworkin (1988: 184) articulates this experience, "the enemy is family ... he is so cruel and so arrogant and so intimate and so close ...". Another kind of enemy is just as difficult to fight. This enemy is the one within - the sexist ideas and life-styles that a woman grew up with, that is difficult to get rid of if they played a strong role in her formative years. This enemy is often the cause of women themselves reinforcing sexist ideas and practices.

The sites of battle also make the struggle against sexism difficult. The sites where sexism must be fought could be found in any part of human life, whether in economy, politics, education, religion, marriage, or sport. Elaine Rapping (1994:17) formulates the complexities of the battle against sexism as follows, "ideological shifts ... take place ... in small, contradictory, multitudinous battles over a variety of issues in a maze of intertextual, contested sites". Thus, feminists must be aware of all possible places and persons where the battle against sexism have not yet been won, while simultaneously being aware where the battle needs not to be fought anymore. The feminist struggle for gender justice does not consist of one decisive battle, but rather of numerous battles of different sizes and a multitude of smaller fights for territory by both individuals and groups.

Many battles and fights have already been won, while quite a few still needs to be fought. Women are not - and never were - mere victims of male domination. Throughout history there are examples of women "whose thought and action do not mesh with an image of downtrodden subordination" (Elshtain, 1981:226). Andrea Dworkin (1988:183) counters the idea of women as mere victims of sexism and celebrates the victories women - as agents responsible for their own destiny - have already won when she says,

... women resist; women fight back; women organize; women are brave; women go up to male power and stop it in its tracks; women fight institutions of male dominance and weaken them; women retaliate against rapists ...; women infiltrate male systems of power; women change laws ...; women provide secret refuge for battered women ...; sometimes women kill; women sue to stop sex discrimination; women claim more and more public space ...; feminists go at male power where it is most dangerous ...; feminists keep thinking, writing, talking, organizing, marching, demonstrating ... 


\section{How should men respond to the feminist movement?}

Men committed to the central values of the South African Constitution should take the feminist movement seriously and respond positively to the fundamental aim of feminists to eliminate all kinds of injustices that women suffer from. These women suffering injustice might be a man's female partner, his daughter, his mother, his friend, or his colleague. Can a man show respect and loving care towards those who share his bed, his genes, his friendship, his work, and his interests if he does not take their experiences of suffering injustice seriously? Perhaps he can show loving care and respect while ignoring and perhaps even contributing to the injustices of the women in his life. However, that respect and loving care will be disfigured and eroded by the injustice contained in them. Gradually the loving care and respect will lose credibility and value if persistent requests for understanding and support in the struggle against injustice are ignored.

Men, as citizens of a modern constitutional democracy like South Africa, experience continually mounting pressures from women as their fellow citizens to support their struggle against sexism. In terms of the South African democratic constitution, women are defined as citizens of equal dignity who have a comprehensive set of rights to equality and liberty. To insist on treatment as free and equal citizens and to demand to jointly work out the details and implications of such treatment in all spheres of life seem a reasonable request. To refuse such a request from any citizen who wish to have nothing more than those rights already assigned to them in a democratic constitution rather seems unreasonable.

Men, as human beings guided in part by moral values, ought to judge the elimination of injustices - that can sometimes cause grievous bodily harm and even death - as a priority. South African men that take moral values seriously ought to have a commitment to minimize remediable suffering and to ensure equitable treatment of all persons, as expressed in the aspirations of the Preamble of the South African Constitution. They ought to have a fallibilist attitude of recognizing the possibilities that their insight into moral values and their awareness of how others experience their society might be flawed. Furthermore, they ought to be open to complaints from aggrieved citizens and be prepared to discuss the feelings of dissatisfaction and being wronged that some people experience. If not, they are morally insensitive and democratically nonresponsive, thus violating the fundamental values of the South African constitutional democracy.

If men have moral obligations to respond positively to feminism, what should they do? Men should be prepared to acknowledge any aspect of 
H.P.P. Lotter

their behaviour in their private or public lives that violate the fundamental values of a modern constitutional democracy. They should be prepared to engage feminists in dialogue about what feminists perceive to be wrong and unjust in terms of shared democratic values or creative extensions thereof. Once men have been convinced of an injustice of sexism, they must be willing to modify their personal behaviour and to make any institutional changes required to eradicate that kind of injustice.

The process of being challenged that some of your actions are sexist and thus humiliate and harm women, might be uncomfortable for some men. They might resist seeing the point of feminists, as they realize that acknowledging guilt might make them lose face or could cost them privileges and comforts they currently enjoy. Some men might thus decide to change only when forced to do so. This is an option for male response to feminism. Men following this option thus only react to feminist pressure and then only grudgingly and unwillingly. To such men Andrea Dworkin (1988:163) issues a simple challenge, "Why are you so slow to understand the simplest things? ... Simply that women are human to the degree and quality that you are".

\section{The proactive option of responding to feminism}

There is another option of how men can respond to the challenge of feminism. This option is voluntary and proactive. It is driven by a fresh interpretation of the fundamental values of the South African Constitution. In this case men discover women as equal partners in a moral quest to reinterpret the fundamental political values of their society and to creatively explore the implications for ensuring liberty and equality that satisfies everyone. In this case men are willing to listen to the most stringent feminist criticism and to take such criticism seriously by responding in earnest with high quality arguments. Such men will be prepared to investigate the past with feminists to determine the harm done to women and to explore ways of undoing or remedying at least some of those harms. They will also be willing to deal with the consequences of injustices of the past that detrimentally affect women in the present.

This willingness to deal with the harms and consequences of past sexist injustices presuppose that such men are open to have their limited horizons on gender relations modified and expanded. Through prolonged interaction and dialogue their horizons might meaningfully fuse with the horizons of feminists. To reach a fusion of horizons would need neverending conversations and dialogues between men and women - in local settings of households to the national setting of Parliament and even to 
the global settings of international organizations like the United Nations and in settings everywhere in between.

In the rest of this article I want to propose one example of reacting to the feminist challenge in terms of the proactive option. The question that will guide my exploration is as follows. What can men committed to the liberal-democratic values of the South African Constitution do to accommodate the legitimate concerns of feminists? I will present four things that men can do. They are as follows. Men must make specific assumptions about gender roles; they must extend the scope of justice to the household; they must develop good judgement of individuals; and they must communicate through genuine dialogue. I will conclude by illustrating how these changes can transform relationships by using the marriage relationship as example.

\section{Assumptions about gender roles}

Men willing to take feminism seriously would have to make the assumption that social roles are not divinely ordained or naturally given, but are made by human beings interacting in communities. If South African citizens are granted rights like freedom of expression, religion, conscience, thought, and opinion, as well as rights to freedom of movement, freedom of association, freedom to choose a profession, and freedom to participate in linguistic and cultural communities of choice, then socially prescribed or divinely ordained roles for women can hardly be imagined. Simone de Beauvoir (1997) rejects the idea that gender roles are natural. Rather, she says, "in human society nothing is natural" and a woman is thus a "product elaborated by civilization" (De Beauvoir, 1997:10). Gender is seen as a social construction that entails far more than mere biological sex. For De Beauvoir (quoted in Butler, 1997:82) "one is not born a woman, but, rather, becomes one". Gender as social construction suggests that men and women do not have fixed natures that will inevitably manifest themselves. Women and men can define themselves, create their own gender, make who they are, and specify who they want to become - this much at least the liberties contained in the South African Constitution allow them.

The freedom of self-creation through which people have open possibilities to negotiate new life-styles to express their gender and their individuality take place within strong constraints. There are biological differences that can affect conceptions of gender. A person's genetic make-up similarly places constraints on what is possible for people to become. Perhaps even more important is Karen J. Warren's (1997:377) remark that "humans are properly understood in terms of networks or webs of historical and concrete relationships". Relations of power from 
the sphere of the household to the larger social sphere can significantly constrain people's options to widen their conceptions of what possibilities they can explore to redefine their ideas of gender.

Feminists have exposed the ways that conceptions of gender have been moulded withın the contours, lımits, and power structures of patriarchal societies These exposures are the beginnings of an awareness that gender is a social construction that can be modified and changed through social and political struggle and protest. Feminists thus want to create space for women to be able to experiment with conceptions of gender and to creatively redefine conceptions of who they are and what they would want to be. Women must have the freedom - granted by the South African Constitution - to choose for themselves whatever characteristics and virtues they find attractive to add to their existing portfolio. Men must not prescribe a gender role with fixed traits to them that places women in the strait jacket of having to be a "lady", for example

Feminists have become aware of the ways that people are affected by full participation in all social spheres and different kinds of activities. Ann Ferguson (1997:77) articulated this awareness as follows, "aspects of our selves are developed by participating in social practices which insist on certain skills and values". For women who had many such activities denied and opportunities closed to them in the past, it has become an exciting exploration to discover how they might develop and change. Development and change presuppose that people do not stay the same. That women - and their conceptions of gender - can thus change significantly throughout their lives has become accepted. Ferguson (1997:77) says that "one's sense of self and one's core values may change at different times and in different contexts".

\section{Justice and the household}

If the various liberties women have, in terms of many different rights embodied in the South African Constitution, allow them to define their own roles through acts of self-creation, what would be the impact on the households women share with male partners? This issue needs further exploration. If one assumes that when people make claims for justice, they do so with the intention to secure for themselves treatment that recognises them as human beings or to gain access to conditions under which they can enjoy the fullest life possible for, and worthy of, human beings (Frankena, 1962:21, 26; Rossouw, 1995:7), then feminism's claim to broaden the scope of justice makes a lot of sense. Ideals of justice in modern constitutional democracies motivated feminists to imaginatively conceptualize their society as more "liberating and enabling" and to 
evaluate current injustices in the light of such imaginary visions (Young, 1990:35). Feminists have also reformulated some ideals of justice and given them new content, enabling women to revise their evaluations of the capacity of their society to provide them adequate space to live worthy lives, appropriately reflecting their human dignity.

Rawls (1971:5) points out that aspects of a conception of justice are always in dispute. Part of such disputes are attempts to apply currently accepted norms and rules of justice to new groups of people or new areas of human interaction. Feminists imaginatively apply the requirements for treating citizens as free and equal to the many complexities of the injustices they classify as sexist. Another aspect of the ever-present disputes about justice in a society is claims for the imaginative discovery and creative development of new ideas of justice that intend to make citizens aware of injustices previously not noticed. To qualify as new ideas of justice, these ideas must gain general acceptance in society and be reasonably coherent with existing, well-established ideas of justice. An example of that is the way in which feminists insist that the household must become a matter of justice as well.

\section{A redefinition of the private and the public}

The arguments for subjecting the household to critical scrutiny in terms of justice are all variants of a plea for a redefinition of the boundary between the private and the public. Feminists reject a spatial definition of the private and the public that would define the household and what happens behinds its doors and curtains as private. They want to open up certain aspects of private lives for public investigation, debate, and evaluation. Feminists do not want to do away with the distinction between public and private, as both are necessary for flourishing human life (cf. Elshtain, 1981:322; Pateman, 1989:134). They certainly do not want total state intrusion into the lives of individuals. However, they do want to open up specific areas of private lives where men dominate and oppress women to bring these issues into view, make them public knowledge, and subject them to collective decision-making. Thus, what is private may imply one of the following aspects: something not to be observed by others, something not to become knowledge available to all interested persons, and something that no other persons or institutions other than the person involved have decision-making power. These three meanings of private do not necessarily always overlap

When feminists argue that the personal should be made political, or the private be made public, they obviously do not want to make intimate sexual acts available for public observation, but they do want to make phenomena like marital rape public knowledge and to be declared acts 
that are illegal so that their perpetrators can be prosecuted in court. They furthermore want to invite public values - those embodied in the South African Constitution like liberty, equality, and human dignity - in through the household door (cf. Benhabib, 1992:13) to influence even their private sexual acts with their partners so that both partners can act as equals in deeply satisfying reciprocal relationships.

\section{Normative evaluation}

Alison Jaggar (1997) argues in favour of treating the household as a matter that must be morally scrutinized in terms of a public conception of justice. She notes that many household issues have been judged to be natural or biologically determined and thus not subject to the dictates of a conception of justice. She judges this assumption of naturalness or biological determination to be what Stuart Hampshire calls a fallacy of false fixity. This fallacy consists of a representation of particular social arrangements as being unalterable or unavoidable features of human life, as they are natural or biologically determined and thus cannot be changed or made otherwise through deliberate, conscious human action (Hampshire, 1989:59). Feminists have shown that many aspects of household life are socially constructed and therefore these assumptions have been proven false. In this light the distinction between a public sphere subject to principles of justice and a private sphere subject only to the values, power, and whims of dominant males "comes to seem philosophically arbitrary, without reason" (Jaggar, 1997:53).

Feminists have succeeded in making several aspects of household life open to normative evaluation in terms of justice. In the light of this evaluation the household emerged as a "site of male power, a power that in its more benign aspects got women working excessively long hours for minimal reward, and in its worst could expose them to physical and sexual abuse" (Phillips, 1991:102). This qualifies as imaginative new applications of existing ideas of justice, that are reasonably coherent with existing, well-established ideas of justice. What qualifies as matters of justice are issues that can be judged in terms of public morality, are remediable by collective human action, and are of public interest. Public interest does not only mean matters that concern a broader public. The well-being of individuals, negatively affected by acts like violence against women, sexual abuse of children, or marital rape, can become public concerns, regardless of the privacy of family life where they take place. The South African Constitution expresses a strong concern about the well-being and dignity of citizens. To protect them from serious harm might force aspects of private, household life open to public inspection and control, like laws on domestic violence, marital rape, and child abuse have already indicated. 
As a result of the feminist struggle to subject households to normative evaluation in terms of a conception of justice based on collective decision-making, Linda J. Nicholson (1997:140) says "the contemporary family has become a very public institution". Feminists have focused a lot of attention on the justice of household life. Two reasons drive their interest in household justice. One is that household life constitutes a very important part of human life where many time-consuming duties and responsibilities are distributed. This distribution drastically affects the opportunities for human development and fulfilment available to women of all ages (Okin, 1989:16). Phillips (1991:102) judges that women under patriarchy suffered not only from the pressures and constraints that denied them opportunities for participation in public activities. Male dominance and oppression created female subordination and submission which made the private, personal sphere for women "as devastatingly destructive of our human development as anything that governments could do".

If other aspects of human life are regulated by public conceptions of justice and fairness, why should the household be withdrawn from moral evaluation? Susan Moller Okin (1989:14) states one reason for the significance of a just family as: "the family must be just if we are to have a just society". This requirement is needed because the family is at the "root of the moral development of individuals" and an "essential foundation" of a just society (Okin, 1989:17). The family has this role because it provides children with formative experiences of how adults interact with each other and with children. Adult interaction can model justice and reciprocity, domination and manipulation, or unequal altruism and onesided self-sacrifice (Okin, 1989:17). The dominating model in a family strongly influences children's ideas about how adults ought to treat one another in a democracy. If South Africans want to establish a deeply rooted human rights culture, adult interaction everywhere must model democratic values to children.

A consistent regard for justice in all spheres of life thus mandates the inclusion of the household in its scope. The role of the household in shaping the values and character of children gives a secondary reason for the urgency of feminists to examine the justice of household life, the primary reason being the unjust division of burdens.

\section{Implementing democratic values in households}

Values, attitudes, and behaviour learnt in the household are taken along into public life. For this reason ensuring appropriate implementation of values like liberty and equality in the household will strengthen South Africa's constitutional democracy. Implementing democratic values in 
H.P.P. Lotter

households, in the sense of imposing such values through third parties, might prove to be difficult. Women should rather be enabled to insist on being treated as democratic citizens with equal dignity and be empowered to claim or enforce their legitimate rights whenever those are threatened by their partners (cf. Phillips, 1991:111, 119). Government officials should step in only when serious, harmful violations of human rights occur (cf. Walzer, 1983:232).

\section{Appropriately judging individuals}

Men interact with many different women in all spheres of life, not only with their partners in households. How should they relate to the individual women they encounter in everyday life? Women have a unique position in society. Women as a group do not have the problems of minority groups whose group identities are not recognized by dominant majorities. On the contrary, Susan Wolf (1994:76) argues, women have been recognized as a distinct group and their separate identity has been exploited by men to justify oppressing and dominating them. Women have also suffered from demeaning stereotypes which dismissed their personal qualities and competencies beforehand. For these reasons feminists are sensitive about appropriate recognition of women's dignity and worth as human beings - a sensitivity fully backed up by the strong emphasis on equal dignity for all citizens in the South African Constitution. Appropriate recognition can mean different things, depending on the context. It seems, though, as if a broad distinction between two issues will satisfy feminist - and most possibly anybody else's concerns. This distinction is between what Seyla Benhabib (1992) calls treating others as the generalized other and treating them as a concrete, specific other.

\section{Awareness of the uniqueness of a person}

Treating individuals as the generalized other implies according them equal respect and dignity as is due every human on the grounds of being a citizen of the South African constitutional democracy. Every woman thus also have rights to equal liberties, equal treatment, equal participation, equal opportunities, and equal consideration of her interests. What equality exactly means in various contexts needs to be jointly determined by all citizens and specified in rights, duties, laws, and policies.

Within the broad moral framework of treating others as the generalized other, there are sufficient spaces for treating others as specific, concrete others. The broad framework sets the minimum requirements for treating others who are encountered personally within a person's everyday life. In addition to the recognition of the general characteristics of a person's 
The South African Constitution requires men to be feminist

humanity, a person's concrete, specific characteristics are recognized and responded to. Treating people according to stereotypes is out Various forms of discrimination are rejected by the South African Constitution, including discrimination on the grounds of sex, gender, pregnancy, or marital status. The emphasis for men ought to be on establishing unique relationships with individual women, whatever the duration. Awareness of the unique features of a person through sensitive observation and attentive listening translates into adapting one's behaviour to suit the uniqueness of a person. Carol Gilligan (1997:276) thus argues that justice in interpersonal relationships "becomes understood as respect for people in their own terms".

Unique relationships are established through determining various factors of importance for establishing that relationship in a specific context Features such as the following must be taken into account: the nature capabilities, and characteristics of the person; the personal and political values of the person; the career and interests of the person, the circumstances and duration of the encounter, and the preceding narrative of the history of their interaction. If men should treat each woman they encounter in whatever context in this unique way in addition to respecting them as the generalized other, they would show true care towards individual women. Carol C. Gould (1997:330) argues that care "translates into responsiveness to the particular needs and interests of individuals or groups instead of treating them all in the very same way".

\section{The link between justice and care}

If justice in these relationships means respect for people in their own terms, and if that implies taking proper care of people, then an intimate link between justice and care becomes apparent. To care for people in interpersonal relationships requires resolution of several issues concerning justice. Care cannot be generalized and be distributed equally, as every person's unique, specific, and concrete needs must be determined (Tronto, 1989:174). Determining needs cannot be done unilaterally, but only in dialogue with the person involved (Tronto, 1989:176-177). How much caring a person receives results from a decision that takes into account the "amount of time and kind of effort that a caring individual can expend" and the needs of the person for whom one cares (Tronto, 1989:180). Caring relationships can easily become unequal power relationships where care-givers keep care-needers dependent on them, as care-givers might themselves need the practice of caring for others (Tronto, 1989:179-180). Justice in this case calls for appropriate relationships between citizens of equal dignity despite the inequalities created by the need for care and the capacity to provide or give care. 
HP.P. Lotter

To treat people according to an appropriate judgement of their individuality seems almost self-evident. Carol Gilligan (1997:275) says that within relationships "the self as moral agent perceives and responds to the perception of need". If the meaning of need can be somewhat stretched, one could argue that men should not treat all women the same, but rather be aware of the different options of what they might have to provide in a relationship with any woman. These options include partnership, care, debate, friendship, distance, support, aid, cooperation, leadership, honour, dialogue, obedience, appreciation, love, emulation, and so on. Men should not, however, unilaterally decide what a relationship needs, as if they are experts in dominant positions. Rather, mutuality and reciprocity must characterise relationships between women and men. Through verbal - and non-verbal - communication, negotiation, and joint decision-making women and men can establish relationships of various kinds which both affirm aspects of their individuality and their shared humanity and for which they share responsibility.

\section{Communication through genuine dialogue}

Dialogue is the most appropriate medium for women and men regardless of the nature of their relationship - to sort out feminist issues and to redefine their relations. Dialogue can be used in ordinary interaction, for decision-making, and for the resolution of conflict. Dialogue works particularly well for relationships experienced as shared projects where it enables genuine communication at deep levels. Dialogue can thus enable understanding between partners, problem-solving, and growth in their relationships. Why is dialogue so appropriate?

Dialogue is a means of human communication that allows people to exchange views, present ideas, and express feelings in a process that treats each partner with equal respect and provides every partner with an equal opportunity to have their interests considered. Partners get a reasonable opportunity to state their case while others listen attentively and take them seriously. Dialogue thus provides every participant the opportunity to make their unique voice heard. Accommodating uniqueness leaves room for opening up and revealing differences. Differences are dealt with in the context of dialogue as mutual quest for reciprocal understanding and new perspectives on both the topic under discussion and on one another. Participants in dialogue must thus be able to tolerate differences and accept that full consensus is not the only possible aim of dialogue, nor should it be seen as the only worthwhile outcome of dialogue.

Dialogue only occurs when participants are equal partners who articulate their own interests and listen with appropriate attention to what others 
have to say. In dialogue the agenda is open and determined by good arguments presented by participants in favour of discussing specific issues. Adequate time must be assigned for dialogue so that issues can be properly debated to the satisfaction of all concerned. A commitment to co-operate in a process of problem-solving provides the impetus to continue searching for adequate solutions. Participants in dialogue must be prepared to learn and grow through the process of dialogue. To do so, they must be willing to listen to criticism of themselves and their views and modify themselves and their positions if good arguments warrant that. Modification is sometimes not enough, as new options might be needed, or equitable, principled compromises must be sought

\section{Equal partners in dialogue}

Participants in a dialogue must regard one another as equal partners who deserve equal respect and consideration in the process of dialogue. Unequal relations of power can distort and destroy dialogue if the more powerful abuse their power to talk down to their supposed inferior partners. In a dialogue the exercise of power over others must be temporarily suspended for the duration of the dialogue. Susan Bordo (1998:25) writes grippingly about her dialogues with her father. She refers to these dialogues as "this conversation, an equal dialogue. between an elderly man and a five-year old girl". What particularly empowered Bordo was the way her father regarded her as worthwhile listening and responding to. So partners in dialogue ought to do

\section{Psychological bullying tactics}

Men are not particularly adept at engaging in sustained dialogue over a long period about all important issues with the women in their lives. Many men would rather punish women with long periods of silence, refusals to discuss matters, psychological bullying tactics, undermining their partner's self-image and self-confidence, and using violence or threats of violence to intimidate and force women into submission to their authority. Unequal physical, financial, or other kinds of power easily convert into dominance that silences dialogue. Unequal power can also scar dialogue when the dominant party sets the agenda unilaterally and thus constrains dialogue. In such cases, Nancy Fraser (1997:370) says, "deliberation [dialogue] can be a mask for domination".

In other cases unequal power in dialogue is the result of one partner using superior abilities of formulation for gaining unfair advantages Many people, and especially oppressed and formerly oppressed groups, might be handicapped here. Fraser $(1997: 370)$ points out that "subordinate groups can sometimes not find the right voice or words to express their thoughts". Further impediments that can ruin dialogue are the tendency 
of men to talk far more than women and thus to deprive them of their rightful opportunities to state their case and make themselves heard. Interruptions, cutting speakers or dialogue short, and silencing participants are more ways of derailing genuine dialogue. Fraser (1997:370) articulates these threats to dialogue neatly when she states that "men tend to interrupt women more than women interrupt men; men also tend to speak more than women, taking more turns and longer turns; and women's interventions are more often ignored or not responded to than men's". Many men would thus have to familiarize themselves anew with the rules of dialogue to move away from an adversarial style to a more co-operative style.

\section{Sort out specific feminist issues}

Men prepared to engage in dialogue with women as equal partners have an open invitation from feminists, says Sandra Harding (1998:182), "to work out for themselves, in dialogue with women feminists, a creative transformation that could have widespread consequences for social relations". What would be on the agenda of this kind of dialogue? One issue would be women's experiences of injustice. Another issue would be women's work. How men ought to look at or view women would also be important, as would men's role in the feminist struggle.

\section{The willingness to listen to women as equals}

To treat women as both equal citizens and as unique individuals with whom they are willing to engage in dialogue with open agendas, implies that men ought to be willing to listen to women's free, unhindered voices. Through listening to women as equals who relate their experiences of injustice and the value of so-called "women's work", men have the opportunity to come to a deep understanding of the main concerns driving feminism. Larry May (1998:344) thinks that men need to spend time "interacting with women in non-dominating ways to learn from them what it is like to be oppressed". Through the ensuing dialogue between women and men, sensitively setting up clear links between women's experiences of injustice and new, jointly determined interpretations of liberal democratic values, women's violated human dignity can be restored and healed. Through these kinds of dialogue many men will lose the blind spots that prevent them from seeing the injustices women suffer from and thus be able to see their roles in maintaining those injustices

If men can succeed in listening to women in a way that makes women feel listened to, Sandra Harding (1998:180) suggests they will develop moral motivation for using the insight they gain critically to "rethink the institutions of society, their cultures and their practices". One example will illustrate the point. Men have dominated politics for centuries and in 
the process have set the political agenda attuned to those issues important to them. Carol C. Gould (1997:335) pleads for a political androgyny which would mean both a joint setting of the political agenda by women and men, as well as a greater role for women and their skills in politics. She (Gould, 1997:334) defines political androgyny as follows, "an importation into the public domain ... of the range of capacities, concerns, and values deriving from women's historical experience, as a corrective for the predominance in public life of historically male concerns and values"

Such reinterpretations of public institutions in the light of women's experiences of injustice must be extended to reinterpretations of men's individual lives, values, and behaviour. Men ought to modify their selfunderstandings and identity in the light of morally justified feminist claims to justice. A specific claim to justice that might cause a considerable rethink on the part of men is women's demand that so-called "women's work" must be appropriately recognized. But more than recognition is demanded. Women also want men to experience the benefits of women's work, especially raising children, and they insist on a more equitable distribution of the burdens involved.

\section{Involvement in mothering functions}

One of the burdens often forced on women is raising children. Women want men to share this burden, but also to experience the numerous benefits of caring for children. Feminists, like Sara Ruddick (1989), have no doubt that mothering children is a worthwhile activity from which men can benefit. Her analysis of mothering indicates three demands that mothers of children must fulfil. One is the satisfaction of basic needs and protection of children through loving care. Children also demand education and nurturance in the sense of stimulating and guiding emotional and intellectual growth. Mothers also have to train their children to become socially acceptable. To fulfil these demands, mothers must be able to think! Ruddick (1989) judges maternal thinking to be a distinct discipline which has characteristic intellectual capacities, judgements, attitudes, and values. A mother, Ruddick (1989:24) argues, "asks certain questions ..., she accepts certain criteria for truth ..., she cares about the findings ..., establishes criteria for determining failure and success, sets priorities, and identifies virtues ..."

The complexities of mothering involve more. Virginia Held (1987:118$119)$ argues that mothering is as creative as manufacturing new products or producing innovative ideas. Mothering shapes a new individual's language, culture, and social skills, making a child literate to become a competent participant in a human community. Mothering also develops 
H.P.P. Lotter

moral values in a new individual that translates into appropriate caring relationships. Adult mothering needs to make itself superfluous through leading children to become autonomous, interdependent persons with their own unique identities. Held (1997) points to the complex judgements mothering requires to gradually guide and empower a child towards growing privacy, autonomy, and self-reliance within relationships of constantly shifting interdependence.

Men can gain several advantages if they become involved in a parenting role that includes mothering functions. Deeper attachments to their children, joy at the growth and development of a child, and inner satisfaction gained through selfless service are some. Judith Kegan Gardiner (1998:268) puts it thus,

The fathers who do daily care, changing diapers and feeding their children, feel themselves relied on, not merely as occasional exciting visitors, and they become intimately attached to their children. Their feelings that they are good fathers, ... may enhance their own esteem and sense of accomplishment.

Feminists warn men involved in parenting to stay modest about their newly adopted roles. Men still have a choice of getting involved in caring for their children, unlike women who are socialized into child-caring roles as their "natural roles" they are obligated to fulfil. In most cases women are the ones with final responsibility for children, without any significant choice and whether they want to or not. Some men's modest involvement thus not yet equalizes the responsibilities and burdens of child care.

Once men understand some of women's issues and experiences better and have chosen to treat women with the respect due to equal citizens and with the recognition due to unique individuals, they can view women with a complex judgement that has many significant values and factors involved. New ways of viewing women would exclude stereotyping, but include seeing women as equals. Furthermore, treating women as individuals would bring awareness of all kinds of differences that must be respected and appropriately responded to. Men must become able to see that some women are like them in important respects, e.g. in being a philosopher. Simultaneously they must be aware that there might be differences between them, e.g. different roles in family life.

\section{The correct response to similarities and differences}

Where and when to respond to similarities and differences can be intuitively grasped and sensitively applied in some cases, whilst being aware of the other person's reaction and feedback. In other cases the nature, conditions, and boundaries of relationships need to be negotiated 
to reach mutual consent about appropriate behaviour. Feminism will have reached an important goal if men would judge women just like they judge other men - continually determining what relationship is possible with another person based on all relevant characteristics and circumstances. Then women could say, as Simone de Beauvoir (1997:11) suggests, "she would seek ... merely a comrade, a friend, a partner, ... a relation between equals", regardless which sphere of life or what kind of human activity forms the context.

In an open dialogue between women and men about women's frustrations with the systematic injustice men perpetrate against women as a distinct group in society, many men may deny any role in committing or perpetuating injustice against women. Some men might truly be blameless. In their case, Andrea Dworkin (1988) says, they need to communicate their innocence to other men in the hope of changing those men to relinquish their sexist life-styles. Similarly, Dworkin advises men who openly express their commitment to equality in the company of feminists to make that commitment true in relation to the women they deal with everyday. Men sharing a commitment to feminist ideals are welcome to participate in the feminist struggle, but are cautioned to play a supporting role rather than trying - again! - to take over women's own struggle. Harry Brod (1998:202) argues in support of men's background role by saying that "insights about gender will more reliably come from women than from men", which makes intuitive sense

There is no doubt that many men resist transformation guided by legitimate feminist aims, because such transformation could undermine ideas and roles they grew up with and judge to be as natural as breathing. Often men are willing to change in some areas of their lives, but not others, as Naomi Wolf (1993:27) describes, "Some men are egalitarians at home and patriarchalists at work, or egalitarians with their daughters and patriarchalists with their wives". David A. Kahane (1998: 222) articulates how disruptive legitimate feminist claims to justice might be on men, "he'd lose his sense of secure grounding in the world - his faith in his own judgements, emotions, and desires. Every aspect of his self would become suspect ...". Lengthy dialogue between women and men exploring all issues in depth, awareness of how human relations and institutions are constructed and reproduced, and shared interpretations of the public values embodied in the South African Constitution, ought to deal with such problems.

\section{Practical application: Marriage}

One of the favourite slogans of the feminist movement is "the personal is political". Okin (1989:124) calls this slogan the core idea of contemporary 
H.P.P. Lotter

feminism and Elshtain (1981:202) describe the overriding imperative of feminists as the attempt to "redefine the boundaries of the public and private, the personal and political". I have earlier argued in favour of an extension of the scope of justice that would bring various aspects of household life under public moral evaluation. I have also argued that women must be judged as unique individuals within a broader framework that entails treating women as citizens of equal human dignity and worth. In the light of these arguments, the feminist slogan can be extended, "If the personal is political, then let's politicize the personal" I want to take marriage as an example of how this would work.

What benefits would result if the central political values embodied in the South African Constitution were applied to marriage relationships? Would politicizing marriage relationships provide reason for sensitive romantics to shudder or would it liberate marriage to become a secure space where two consenting adults of equal dignity can establish a reciprocally defined, meaningful, enriching, and mutually rewarding relationship? I hope to establish the second option. To do this, I first apply the rights, that the South African constitution grants to women as equal citizens, to marriage relationships. Next I apply dialogue as the preferred style of human communication to decision-making in marriage relationships. Lastly I draw some implications for sex in marriage.

It seems absurd to suggest that a woman as citizen of a liberal democracy leaves her human rights, granted to her by her country's constitution, outside when she enters the home she shares with her partner in marriage. For what reason could a marriage relationship nullify her right to life so that her husband could murder her? Could any reason nullify her right to be free from all forms of violence, so that her husband could physically abuse her if he thinks she needs to be "disciplined"? Any suggestion that marriage implies a relationship where one or both partners have no human rights like these against the other seems almost too incomprehensible to consider.

Carole Pateman (1989:219) correctly asks whether a person can be "at one and the same time, a free democratic citizen and a wife who gives up a vital aspect of her freedom and individuality, the freedom to refuse consent and say 'no' to the violation of the integrity of her person?" Anne Phillips (1991:30) is even more blunt in her remark that feminists stress that "inequalities in marriage and the household make a nonsense of equal political rights". She argues that women's experiences in their households "continually undercut the possibilities for democracy" and thus political equality requires "substantial changes in the domestic sphere" (Phillips, 1991:99-100). 
If rights to life and to be free from violence apply inside marriage as much as they do outside, what about other rights? Should they not be fully valid in marriage relationships as well? A right similar to the one to be free from all forms of violence is that no person may be treated in a cruel, inhuman, or degrading way. Could there be good reasons to grant a marriage partner the freedom to treat the other partner in this way? Or should one rather suggest that a liberal democratic state protecting its citizens from cruel, inhuman, and degrading treatment in the public sphere ought to have an interest in protecting them in the private sphere as well? Once cruel, inhuman, and degrading treatment manifests in a marriage relationship, true love takes a back seat or has disappeared. In such cases the state ought to intervene to protect the suffering partner from severe physical or psychological harm. If this is the case, then marriage partners ought to have such rights against one another.

The argument underlying the remarks about human rights and marriage thus far is the following. A marriage relationship does not nullify the human rights citizens in any modern constitutional democracy are accorded by the constitutions operative in their countries. If this idea is convincing as far as rights go that intend to prevent serious harms, what about other rights? If "everyone" has the right to make decisions concerning reproduction, it is difficult to see what kind of reason can take that right away from a woman in marriage (RSA Const., 1996: Art. 12, par. [2] a). It is unthinkable that her husband could make this decision for her, as that would place her in a position of a minor in relation to her husband - clearly not justifiable to a free and equal citizen. At most a woman could be required to make a joint decision about reproduction with her husband, based on dialogue that leads to consensus. This consensus must not result from any form of coercion or intimidation. In cases where partners fail to reach consensus, the right of "everyone" to make decisions concerning reproduction comes alive again to protect the women against being coerced or forced into something that radically affects her body.

Similar arguments can be made for rights to privacy, freedom of thought, expression, association, movement, and protest that women have according to the South African Constitution. These rights ought to trump any other considerations that would allow one partner to dominate and rule the personal life of an equal citizen assigned all the customary democratic liberties by a country's constitution. Only in cases when a partner voluntarily waives a right without any coercion or intimidation involved, can a marriage be considered to be free from the demands of such rights. Waiving rights simply to "preserve the peace", which mostly means keeping a dominating partner satisfied so that the partner does 
not do further harms, already suggests a relationship where coercion and intimidation have invaded spaces for free decision-making.

If marriage is a relationship between two free and equal citizens with all their human rights operative in their relationship, then how ought they to make decisions about their shared interests and responsibilities? The process of decision-making lies at the root of most cases of marital oppression and many deep frustrations result when that process is unfair and privileges one partner at the expense of the other. This process of decision-making is important as a result of the wide range of issues it potentially draws within its scope.

Marriage partners share most of the following interests and responsibilities about which decisions must be made. They must manage their own love relationship by spending time together, giving each other sufficient attention of the right kind, and taking care of each other as need arises. Their sexual relationship is linked to all the issues previously mentioned, but include intimate and private aspects of their bodies, minds, and values as well, making it a particularly sensitive area. Sexual relationships mostly lead to offspring that place high demands in terms of resources and care. A wide range of issues needs to be decided, the division of joys, responsibilities, and burdens that care for children requires from both marriage partners. Marriages are about many more kinds of human relations, of which relations with in-laws, friends, and colleagues have not even been mentioned as shared interests! Marriage partners - depending on their socio-economic status - also share various kinds of assets, that may include a residence, household goods, vehicles, a garden, investments, and so on. Their assets need care, such as maintenance, cleaning, administration, and replacement.

How do two free and equal South African citizens in a marriage relationship divide the benefits and burdens of their shared interests and responsibilities? In the light of the strong value of autonomy underlying the human rights of the South African constitutional democracy, the marriage partners must make those decisions for themselves without being prescribed to from outside their relationship. If they have the responsibility to make out these issues for themselves, there is no other way than joint decision-making based on dialogue. Both partners must be willing to submit to this process and abide by its outcomes. If they realistically determine their individual strengths and weaknesses, recognize their talents, and take account of their available time, they ought to be able to reach a fair division of benefits and burdens that would be appropriate for their personal characteristics and circumstances. 
Someone might object that marriage partners have no mechanism to break deadlocks when they strongly disagree, as they would always be stuck with their voting resulting in a tie. This objection fails to take account of the context of decision-making. Decision-making in marriage is not only between two partners responsible for shared interests and duties. The partners making decisions are not only equal partners, but also friends and lovers. Autocratic decisions against the will of a partner and negatively affecting that partner's life will have repercussions on their friendship, their love life, and sexual relations. Sichtermann (1986:10) eloquently formulates the link between sex and other aspects of marriage

An orgasm is the last in a chain of experiences, of images, dreams, longings and anxieties, all sensations which unfold outside the bedroom. It is the last in a chain of impressions, expectations, disappointments, surprises, looks and touches.

Sichtermann continues to explicitly link women's problems in experiencing orgasm to the "time, behaviour, and experience before the event" (Sichtermann, 1986:11). Mistreating a partner in decision-making will thus have its own penalties. Integrity in marriage is thus required, treating a partner according to the same values and with the same respect throughout all dimensions of marriage.

What implications does a view of marriage as an institution limited by both partners' human rights, where decision-making takes place on the basis of equal partners engaging in dialogue, have for sex between the partners? Although sex is an "archetypically private act," Jane Mansbridge argues that "patterns of sexual interaction encode and maintain patterns of unequal power that reverberate beyond the private realm" (Mansbridge, 1993:64). Equality - or its absence - in a relationship can make a major difference to sexual relations. In a marriage relationship where a husband strongly dominates, the sexual act resembles sex between cattle. No foreplay, no mutuality, no elegance, and no sensitivity is involved. Only a brief penetration when the cow allows the bull when she intuitively knows that she is physiologically ready for the act. Simone de Beauvoir (1997:12) eloquently articulates this kind of sex between humans:

[a] woman feels herself profoundly passive in the sexual act ... [they] still envisage their erotic life from the standpoint of the tradition of slavery, since it seems to them humiliating to lie beneath the man, to be penetrated by him, they grow tense in frigidity.

In contrast to sex between cattle, ostriches show a different approach. Eloquent foreplay consisting of a dazzling display of black and white feathers in a lover's dance precedes the sexual act to which the female 
gives explicit consent. This comparison is much closer to sex between equal human partners, although still much poorer in content and meaning. Perhaps ostrich lovemaking still have too much of males being the desiring subjects who are to become conquerors of the females, while the females play too much of the role of seductress who are content to be the desired object (cf. Sichtermann, 1986:7-11).

Equality in human sexual relations requires more than eloquent foreplay between desiring conquerors and desirable seductresses. Sichtermann (1986:12) argues for expansive sexual roles without firmly set patterns, but rather consisting of "possible behaviour patterns with room for an array of behaviour patterns". In such roles, women and men would both be subject and object, desirer and the desired, as some of the possibilities to be played out during sexual interaction. As a result, sexuality would become a "union of male-female activity and passivity" (Sichtermann, 1986:119). In sexual relations characterized as being reciprocally interdependent, both partners would be deeply satisfied. In relations of domination where men deny women opportunities to express their desires and to actively explore their own fulfilment, both partners are harmed (Sichtermann, 1986:119). If one partner is deprived of freedoms and opportunities enjoyed by the other, both will suffer, as the level of sexual satisfaction experienced by one partner is strongly affected by the satisfaction - or lack thereof - experienced by the other (Sichtermann, 1986:119).

Where human sexuality have open spaces within a secure relationship, partners can be themselves with someone they trust implicitly. They can reveal their innermost being in a relationship where emotional intimacy exists that enables them to share their deepest feelings with their partner. As equal partners they take the initiative in turn to guide their partner to deeper levels of intimacy and pleasure that enrich their shared love. De Beauvoir (1997:12) articulates this kind of sex from her viewpoint as a woman, "... she, like him, is a consenting, a voluntary gift; they live out in their several fashions the strange ambiguity of existence made body

\section{Feminist men in South Africa?}

How should South African men react to legitimate feminist claims to justice that are supported by the central values of the South African Constitution? Should men grudgingly grant women new spaces justified by their legitimate claims to justice, or should they willingly and gladly give women the spaces owed them long ago? To "grudgingly grant" suggests a willingness to allow women in new spaces and to give them their legitimate places. What is noticeably absent is a new attitude 
welcoming women to full status as equals and rejoicing about the elimination of injustice. To "willingly and gladly give" suggests changed ideas and attitudes about women that welcome them as full and equal partners who have been liberated from oppression and domination. Feminist men are men with this attitude.

Must South African men become "feminist men"? If a feminist man means a man docilely accepting feminist views, no. Such a man would be too confused by the wide variety of feminist theories currently available. If a feminist man means a man that constructively engage feminists in dialogue as equal South African citizens with the aim of addressing their claims to justice in partnership with them, then the answer is yes. Yes, if you like to be labelled or to be placed in a category; if not, a feminist man can simply be called a person who has become more human through eliminating injustice that he might have been co-responsible for, through having more meaningful relations with women as equals, and through deeper appropriation and implementation of the shared public values South Africans chose as foundational for their society.

\section{Bibliography}

BENHABIB, Seyla. 1992. Situating the self: Gender, community and postmodernism in contemporary ethics New York: Routledge

BORDO, Susan. 1998. My father the feminist. (/n Digby, Tom, ed Men doing feminism. New York \& London : Routledge p. 17-33.)

BROD, Harry. 1998. To be a man, or not to be a man - that is the feminist question (In Digby, Tom, ed. Men doing feminism. New York \& London : Routledge p. 197-212.)

BUTLER, Judith. 1997 Selection from gender trouble. (In Gould, Carol C. Key concepts in critical theory: Gender. New Yersey : Humanities Press. p. 80-88)

CHODOROW, Nancy. 1997. Selection from gender, relation, and difference in psychoanalytic perspective. (In Gould, Carol C. Key concepts in critical theory: Gender. New Jersey : Humanities Press. p. 25-40.)

COLLINS, Patricia Hill. 1997 Selection from black feminist thought. (In Gould, Caro C. Key concepts in critical theory: Gender. New Jersey: Humanities Press. p. 159-171.)

DE BEAUVOIR, Simone. 1997. Selection from the second sex. (In Gould, Carol C Key concepts in critical theory: Gender. New Jersey : Humanities Press. p. 3-15)

DWORKIN, Andrea. 1988. Letters from a war zone: Writings 1976-1987. London Secker \& Warburg

ELSHTAIN, Jean Bethke. 1981. Public man, private woman: Women in social and political thought Oxford: Martin Robertson

FERGUSON, Ann 1997. Selection from a feminist aspect theory of the self. (In Gould, Carol C. Key concepts in critical theory: Gender. New Jersey : Humanities Press. p. 66-73.)

FRANKENA, William K 1962 The concept of social justice. (In Brandt, Richard B ed. Social Justice. Englewood Cliffs, N.J. : Prentice-Hall. p. 1-29.) 
FRASER, Nancy. 1997. Selection from rethinking the public sphere: A contribution to the critique of actually existing democracy (In Gould, Carol C. Key concepts in critical theory: Gender New Jersey: Humanities Press. p. 369-374.)

GARDINER, Judith Kegan 1998 Femınısm and the future of fathering. (In Digby, Tom, ed Men doing femınısm New York \& London : Routledge. p. 255-274.)

GILLIGAN. Carol 1997 Selection from moral orientation and moral development (In Gould Carol C Key concepts in critical theory Gender New Jersey: Humanities Press p 272-281)

GOULD. Carol C 1997 Selection from feminısm and the democratic community revisited (In Gould, Carol C Key concepts in critical theory: Gender. New Jersey : Humanities Press. p. 325-336)

HAMPSHIRE, Stuart 1989 Innocence and experience London: Penguin Books

HARDING, Sandra. 1998. Can men be subjects of feminist thought? (In Digby, Tom, ed. Men doing feminism. New York \& London : Routledge p. 171-196.)

HELD, Virginia. 1987 Non-contractual society: A feminist view. (In Hanen, Marsha \& Nielsen, Kai, eds. Science, morality, and feminist theory: Canadian Journal of Philosophy, Supplementary volume, 13:111-137.)

JAGGAR, Alison. 1997. Selection from human biology in feminist theory. (In Gould, Carol C. Key concepts in critical theory: Gender. New Jersey : Humanities Press p. 48-55.)

KAHANE, David J 1998. Male feminism as oxymoron. (In Digby, Tom, ed Men doing feminism. New York \& London : Routledge. p. 213-236)

MANSBRIDGE, Jane 1993. Feminsm and democratic community. (In Chapman, J. \& Shapiro, I. Democratic community New York: New York University Press p. 339-395.)

MAY, Larry 1998 A progressive male standpoint. (In Digby, Tom, ed. Men doing feminism New York \& London : Routledge. p. 337-353.)

NARAYAN, Uma 1997. Selection from the project of feminist epistemology Perspectives from a non-Western feminist. (In Gould, Carol C Key concepts in critical theory: Gender New Jersey : Humanities Press p. 172-179.)

NICHOLSON, Linda J. 1997. Selection from gender and history. (In Gould, Carol C Key concepts in critical theory: Gender. New Jersey : Humanities Press. p.139147.)

OKIN, Susan Moller. 1989 Justice, gender, and the family. New York: Basic Books.

PATEMAN, Carole. 1989 The disorder of women: Democracy, feminism and political theory Cambridge, England: Polity Press.

PHILLIPS, Anne. 1991. Engendering democracy. University Park, Pennsylvania : The Pennsylvania State University Press

RAPPING, Elaine. 1994. Gender and media theory: A critique of the "Backlash model". Journal of Social Philosophy, XXV:7-21

RAWLS, John 1971. A theory of justice. Oxford: Oxford University Press.

REPUBLIC OF SOUTH AFRICA. (1996) Constitution of the Republic of South Africa Bill. Cape Town : Constitutional Assembly, 8 May.

RICHARDS, Janet Radcliffe 1994. The sceptical feminist London: Penguin Books

ROSSOUW, HW. 1995. Die begrip geregtigheid. Unpublished paper delivered at the Department of Philosophy, Rand Afrikaans University, Johannesburg.

RUDDICK, Sara. 1989. Maternal thinkıng: Towards a politics of peace London: The Women's Press

SICHTERMANN, Barbara. 1986. Femininity: The politics of the personal. Translated by John Whitlam. Edited by Helga Reyer-Ryan. Minneapolis : University of Minnesota Press. 
The South African Constitution requires men to be feminist

STERBA, James $P$ 1998. Justice for here and now. Cambridge : Cambridge University Press.

SUPERSON, Anita M 19?

TRONTO, Joan C. 1989. Women and caring. What can feminists learn about morality from caring? (In Jaggar, Alison M. \& Bordo, Susan R. Gender/Body/Knowledge Feminist reconstructions of being and knowing New Brunswick \& London : Rutgers University Press. p. 172-187.)

WALZER, Michael 1983. Spheres of justice: A defense of pluralism and equality Oxford: Blackwell.

WARREN, Karen J. 1997. Selection from the power and the promise of ecological feminism. (In Gould, Carol C. Key concepts in critical theory: Gender New Jersey: Humanities Press. p. 375-383.)

WOLF, Naomi. 1993. Fire with fire: The new female power and how it will change the 21st century. London : Vintage

WOLF, Susan. 1994. Comment. (In Taylor, Charles \& Gutmann, Amy, ed. Multiculturalism: Examining the politics of recognition Princeton, $\mathrm{N} \mathrm{J}$ : Princeton University Press p 78-85.)

YOUNG, Iris Marion 1990. Justice and the politics of difference. Princeton, N.J. Princeton University Press

\section{Key concepts:}

feminism - a philosophy of liberation

rights violations

South African Constitution: fundamental values of justice

women's rights - moral concerns

\section{Kernbegrippe:}

feminisme - ' $n$ bevrydingsfilosofie

skending van regte

Suid-Afrikaanse Grondwet: grondliggende reg en waardes

vroueregte - morele aangeleenthede 